\title{
Systemic Effects of Orally-Administered Zinc and Tin (IV) Metalloporphyrins on Heme Oxygenase Expression in Mice
}

\author{
ICHIRO MORIOKA, RONALD J. WONG, AIDA ABATE, HENDRIK J. VREMAN, CHRISTOPHER H. CONTAG, \\ AND DAVID K. STEVENSON \\ Department of Pediatrics [I.M., R.J.W., A.A., H.J.V., C.H.C., D.K.S.], Stanford University School of Medicine, Stanford, CA 94305; \\ Department of Pediatrics [I.M.], Kobe University Graduate School of Medicine, Kobe 650-0017, Japan
}

\begin{abstract}
Some metalloporphyrins (Mps) inhibit heme oxygenase (HO), the rate-limiting enzyme in the production of bilirubin, and are potential compounds for the treatment of neonatal jaundice. We studied the safety and efficacy of Mps following oral administration. Adult HO-1-luc reporter mice were administered $30 \mu \mathrm{mol} / \mathrm{kg}$ body weight of tin mesoporphyrin (SnMP), zinc bis glycol deuteroporphyrin $(\mathrm{ZnBG})$, or zinc protoporphyrin $(\mathrm{ZnPP})$, or vehicle by oral gavage. Bilirubin production was measured as total body carbon monoxide (CO) excretion (VeCO). HO activity was quantitated via $\mathrm{CO}$ measurements by gas chromatography. HO-1 protein was determined by Western blot. HO-1 transcription levels were assessed by in vivo bioluminescence imaging. A significant $28 \%$ decrease in bilirubin production occurred within $3 \mathrm{~h}$ of SnMP treatment and persisted beyond $48 \mathrm{~h}$. Bilirubin production decreased $15 \%$ and $9 \%$ by $3 \mathrm{~h}$ after administration of $\mathrm{ZnBG}$ and $\mathrm{ZnPP}$, respectively, but returned to baseline within $48 \mathrm{~h}$. Maximal inhibition of liver, spleen, and intestine $\mathrm{HO}$ activity was seen at $3 \mathrm{~h}$ with inhibitory effects decreasing in the order: SnMP $\geq \mathrm{ZnBG} \geq \mathrm{ZnPP}$. After SnMP treatment, HO-1 transcription increased 5.7-fold after $24 \mathrm{~h}$. Furthermore, liver and spleen HO-1 protein significantly increased 3.7- and 2.0-fold, respectively, after $24 \mathrm{~h}$. HO-1 transcription and protein were not affected in ZnBG- or ZnPP-treated mice. We conclude that the three Mps are absorbed at different rates in the mouse and affect bilirubin production and HO-1 expression in a tissue- and time-dependent manner. (Pediatr Res 59: 667-672, 2006)
\end{abstract}

$\mathrm{A}^{\prime \prime}$ 11 neonates transiently present with jaundice, resolving within 1 wk after birth. However, some neonates develop pathologic jaundice, usually caused by hemolytic disease, closed-space bleeding, genetic factors, or prematurity. These conditions are often associated with an increased production of bilirubin superimposed on an immature hepatic bilirubin conjugation and excretion system. At pathologically high bilirubin levels (hyperbilirubinemia), there is an increased risk for developing acute bilirubin encephalopathy and, if chronic, kernicterus. The standard treatment for hyperbilirubinemia is phototherapy or, when severe, exchange transfusion either alone or in combination with phototherapy. These therapies only remove the bilirubin that is produced or

Received August 19, 2005; accepted January 5, 2006.

Correspondence: Ronald J. Wong, M.D., Department of Pediatrics, Stanford University School of Medicine, 300 Pasteur Drive, Rm S230, Stanford, CA 94305-5208; e-mail: rjwong@stanford.edu

This work was supported by the Mary L. Johnson Research Fund, Christopher Hess Research Fund, and National Institutes of Health grants HL58013 and HL68703.

DOI: 10.1203/01.pdr.0000215088.71481.a6 has accumulated in circulation and tissues. A more ideal strategy would be to suppress the formation of bilirubin.

Heme oxygenase (HO) is the enzyme in the heme degradation pathway, where equimolar quantities of ferrous iron $\left(\mathrm{Fe}^{2+}\right)$, carbon monoxide $(\mathrm{CO})$, and biliverdin are produced $(1,2)$. Biliverdin is immediately reduced to bilirubin by biliverdin reductase. Thus, by inhibiting HO activity, the formation of bilirubin can be suppressed.

Metalloporphyrins (Mps) consist of a central metal (e.g., tin, zinc, etc.) and a porphyrin macrocycle [i.e., mesoporphyrin (MP), protoporphyrin (PP), or deuteroporphyrin IX 2,4bis(glycol) (BG)]. Some Mps are competitive inhibitors of $\mathrm{HO}$ and derivatives of heme and, therefore are being evaluated as drugs for the treatment of jaundice (3-6). Clinical studies have shown that $6 \mu \mathrm{mol} / \mathrm{kg}$ body weight (BW) of tin mesoporphyrin [SnMP or Stannsoporfin (InfaCare Pharmaceuticals, Neptune, NJ)] has therapeutic value (7-10). However, Mps can potentially affect important enzymes other than $\mathrm{HO}$, such as nitric oxide synthase (NOS) and soluble guanylyl cyclase (sGC) (11), lipid peroxidation (12), and HO-1 gene expression $(13,14)$, and some are phototoxic $(15,16)$. By inducing HO-1 gene expression, Mps may increase HO-1 protein and increase bilirubin formation, therefore negating their clinical utility, especially in patients with an increased heme load, as in hemolytic diseases or closed-space bleeding.

SnMP was chosen because it is not only a potent HO inhibitor $(3,17)$, but also has been used in clinical studies (7-10). Zinc bis(glycol) deuteroporphyrin (ZnBG) was selected because it is also a potent $\mathrm{HO}$ inhibitor $(4,17)$ and orally absorbed by neonatal rats (18). In addition, it does not affect NOS or sGC at low concentrations (11) nor HO-1 gene expression in mice (14). Finally, zinc protoporphyrin (ZnPP) was chosen because it is occurs in nature, has moderate inhibitory effects on $\mathrm{HO}$ and seems to be less phototoxic than SnMP $(15,17)$, though it is a potent singlet oxygen sensitizer in vitro (19). It can accumulate under pathologic conditions, such as chronic anemia and lead poisoning. Here, we inves-

Abbreviations: BLI, bioluminescence imaging; BW, body weight; GC, gas chromatography; HO, heme oxygenase; luc, luciferase; Mps, metalloporphyrins; SnMP, tin mesoporphyrin; VeCO, total body carbon monoxide excretion; ZnBG, zinc bis glycol porphyrin; ZnPP, zinc protoporphyrin 
tigated the safety and efficacy of oral SnMP, ZnBG, and ZnPP by assessing their effects on bilirubin production, $\mathrm{HO}$ enzyme activity, $\mathrm{HO}$ protein, and HO-1 transcription rates in a mouse model.

\section{MATERIALS AND METHODS}

Animals. The study was approved by the Institutional Animal Care and Use Committee at Stanford University. Adult (6-8 wks, 15.3 to $22.8 \mathrm{~g}$ ) female transgenic ( $\mathrm{Tg}$ ) mice, with the transgene containing a 15-kb HO-1 promoter driving expression of the reporter gene luciferase (luc, HO-1-luc) (20) were obtained from the Stanford Transgenic Animal Facility (Stanford, $\mathrm{CA})$ and provided water and food ad libitum.

Reagents. Mps: SnMP (6.0 mg), ZnBG $(5.6 \mathrm{mg})$, and $\mathrm{ZnPP}(5.0 \mathrm{mg})$ (Frontier Scientific, Logan, UT), were dissolved in $60-\mu \mathrm{L} 0.4 \mathrm{M} \mathrm{Na} \mathrm{PO}_{4}$. After addition of $250-\mu \mathrm{L} \mathrm{H}_{2} \mathrm{O}, 1-\mathrm{mL} 0.9 \%$ saline was added and the $\mathrm{pH}$ was adjusted to $7.4-7.8$ with $1 \mathrm{M} \mathrm{HCl}$. The volume was then adjusted to 2 -mLwith saline to yield $4 \mathrm{mM}$ stock solutions. Vehicle: Vehicle was prepared similarly without the addition of Mps. All solutions were stored at $4^{\circ} \mathrm{C}$ in the dark until use for up to $1 \mathrm{wk}$. Methemalbumin: A stock solution of methemalbumin [(1.5 $\mathrm{mM}$ heme/0.15 mM BSA (BSA)] was prepared by dissolving $9.9 \mathrm{mg}$ of hemin (Sigma Chemical Co., Aldrich, St. Louis, MO) in 2.5-mL 0.4M Na $\mathrm{PO}_{4}$. 100-mg BSA (Sigma Chemical Co.) was added, and the volume adjusted to 8 - $\mathrm{mL}$ with distilled water. $\mathrm{pH}$ was then gradually titrated to 7.4 with $1 \mathrm{M} \mathrm{HCl}$ under constant stirring. $\mathrm{H}_{2} \mathrm{O}$ was added to a final volume of $10 \mathrm{~mL}$. NADPH: $4.5 \mathrm{mM}$ solution was prepared by dissolving $4.2 \mathrm{mg} \mathrm{NADPH}$ in $1-\mathrm{mL} 0.1 \mathrm{M}$ $\mathrm{K}_{2} \mathrm{HPO}_{4} / \mathrm{KH}_{2} \mathrm{PO}_{4}$ buffer, $\mathrm{pH}$ 7.4.

Oral administration. Mice were randomly distributed into four groups [control (vehicle), SnMP, ZnBG, or ZnPP]. After baseline total body CO excretion (VeCO), an index of in vivo bilirubin production rate (21), and HO-1 transcription levels had been measured (see below), mice were given vehicle or $30 \mu \mathrm{mol}$ of $\mathrm{SnMP}, \mathrm{ZnBG}$, or $\mathrm{ZnPP} / \mathrm{kg}$ BW in a single bolus by oral gavage in volumes $\leq 250 \mu \mathrm{L}$ using a $1.0-\mathrm{mL}$ syringe fitted with a blunt gavage needle.

VeCO. In vivo bilirubin production rates $(\mathrm{VeCO})$ were determined by gas chromatography (GC) as described previously $(6,22)$. Each mouse was weighed and placed in a $50-\mathrm{mL}$ chamber supplied with $\mathrm{CO}$-free air at a flow approximately $40-50 \mathrm{~mL} / \mathrm{min}$. After $30 \mathrm{~min}$, the CO concentration (ppm) in the chamber outlet gas was measured by GC every $90 \mathrm{~s}$, calculated as $\mu \mathrm{L}$ $\mathrm{CO} / \mathrm{h} / \mathrm{kg} \mathrm{BW}$, and expressed as \% of baseline.

In vivo bioluminescence imaging (BLI). In vivo $\mathrm{HO}-1$ transcription was assessed by BLI using the In Vivo Imaging System (IVISTM, Xenogen, Alameda, CA) as described previously $(13,14,20)$. Briefly, 10-20 min before imaging, mice were injected intraperitoneally (IP) with 50-mg Nembutal $/ \mathrm{kg}$ $\mathrm{BW}$ and $150 \mathrm{mg}$ luciferin/kg BW. Sedated mice were then placed in the IVIS. Photons emitted were calculated as flux (photons emitted/s) using LivingImage (Xenogen), expressed as fold change from basal levels, and then normalized to that of control animals.

Tissue preparation. After animals were killed, liver, spleen, and small intestine were harvested, immediately rinsed with ice-cold buffer, and divided as follows: $100 \pm 2 \mathrm{mg}$ whole tissue was immediately placed in $1.5-\mathrm{mL}$ microfuge tubes containing RNAlater (Qiagen Inc., Valencia, CA). Tubes were stored at $4{ }^{\circ} \mathrm{C}$ overnight and then at $-20^{\circ} \mathrm{C}$ until isolation of total RNA. Another $100 \pm 2 \mathrm{mg}$ tissue was placed in a $2.0-\mathrm{mL}$ polypropylene microfuge tube, diced in $900-\mu \mathrm{L}$ buffer, and sonicated on ice at $50 \%$ power with an ultrasonic cell disruptor with an ice-cold 1/8" microprobe (Model XL2000, Misonics Inc., Farmingdale, NY). Sonicates were kept on ice and HO activity measured within $1 \mathrm{~h}$. $500-\mu \mathrm{L}$ of sonicate was added to a $1.5-\mathrm{mL}$ polypropylene microfuge tube containing $0.5-\mu \mathrm{L}$ protease inhibitor and flash frozen with liquid nitrogen before storage at $-80^{\circ} \mathrm{C}$ until measurements of $\mathrm{HO}$ proteins.

In vitro HO activity. $20-\mu \mathrm{L}$ tissue sonicate $[2 \mathrm{mg}$ fresh weight $(\mathrm{FW})]$ was incubated for $15 \mathrm{~min}$ at $37^{\circ} \mathrm{C}$ in CO-free septum-sealed 2-mL vials containing $20-\mu \mathrm{L} 150 \mu \mathrm{M}$ methemalbumin and $20-\mu \mathrm{L} 4.5 \mathrm{mM}$ NADPH as previously described $(23,24)$. Blank reaction vials contained phosphate buffer in place of NADPH. Reactions were terminated by the addition of 5- $\mu \mathrm{L} \mathrm{30 \%} \mathrm{sulfosali-}$ cylic acid and the vials place on ice. The amount of $\mathrm{CO}$ generated by the reaction and released into the vial headspace was quantitated by GC. HO activity was calculated as $\mathrm{pmol} \mathrm{CO} / \mathrm{h} / \mathrm{mg} \mathrm{FW}$ and expressed as \% of $\mathrm{HO}$ activity left.

Proteins. Protein concentrations of (1:100) tissue sonicates were determined using Bio-Rad Protein Assay kit (Bio-Rad, Hercules, CA).

mRNA levels of luc and HO-1. luc and HO-1 mRNA levels were quantified by real-time RT-PCR using a GeneAmp 5700 Sequence Detection System (Perkin-Elmer, Wellesley, MA). Total RNA in liver, spleen, and
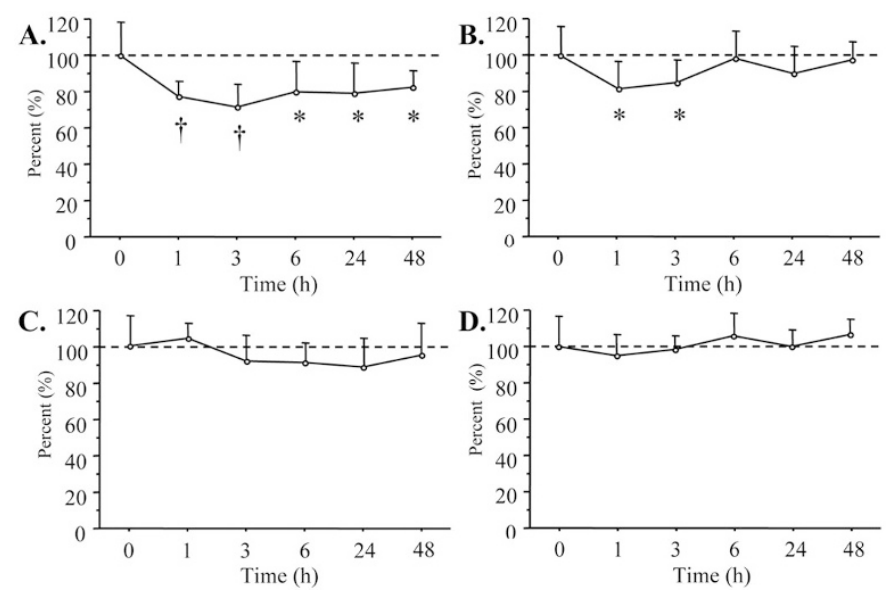

Figure 1. In vivo bilirubin production rates $(\mathrm{VeCO})$ were measured as $\mu \mathrm{L}$ $\mathrm{CO} / \mathrm{h} / \mathrm{kg} \mathrm{BW}$ at $1,3,6,24$, and $48 \mathrm{~h}$ after oral administration of $30 \mu \mathrm{mol} / \mathrm{kg}$ $\mathrm{BW}$ of $\mathrm{SnMP}(A), \mathrm{ZnBG}(B), \mathrm{ZnPP}(C)$, or vehicle $(D)$ and expressed as mean $\pm \mathrm{SD} \%$ of baseline $\operatorname{VeCO}(n=5-9$ for each time point $) . \dagger p<0.01, * p<$ 0.05 compared with the baseline.

intestine of control and SnMP-treated mice was extracted from archived samples using the RNAeasy Mini Kit (Qiagen Inc.). One-step RT-PCR was performed in a MicroAmp optical 96-well plate, each well containing 40-ng total RNA with HO-1 or luc primers and the QuantiTect SYBR Green RT-PCR kit (Qiagen Inc.). Thermocycles were set as follows: $50^{\circ} \mathrm{C}$ for 30 min, $95^{\circ} \mathrm{C}$ for $15 \mathrm{~min}$ and 40 cycles of $95^{\circ} \mathrm{C}$ for $15 \mathrm{~s}, 60^{\circ} \mathrm{C}$ for $30 \mathrm{~s}$, and $72^{\circ} \mathrm{C}$ for $30 \mathrm{~s}$. Copy number per $\mu \mathrm{g}$ total RNA per sample was calculated from a standard curve using standards of $\mathrm{HO}-1$ and luc mRNA, normalized to $\beta$-actin, and then expressed as fold change from control levels.

Western blots. 100, 50,150 $\mu \mathrm{g}$ of liver, spleen, and intestine protein sonicate, respectively, were mixed with an equal volume of loading buffer. Samples were separated on a $12 \%$ polyacrylamide gel, and then transferred to polyvinylidene difluoride membranes (Millipore, Bedford, MA). After being blocked in Tween-PBS with 5\% milk, membranes were incubated with polyclonal HO-1 antibody $(1: 1,000)$ raised against a $30-\mathrm{kDa}$ soluble $\mathrm{HO}-1$ protein expressed in Escherichia coli from rat liver cDNA (gift of Angela Wilks, University of Maryland, Baltimore, MD) by Berkeley Antibodies Inc. (Berkeley, CA) or polyclonal HO-2 antibody $(1: 2,000)$ (Stressgen, Victoria, $\mathrm{BC}$ ) for $1 \mathrm{~h}$. Membranes were washed, and then incubated with anti-rabbit IgG-HRP $(1: 7,000)$ (Santa Cruz Biotechnology, Santa Cruz, CA) in TweenPBS with 5\% milk for 30 min. After washing, immunocomplexes on the membranes were visualized with ECL Western Blotting Detection Reagents (Amersham Biosciences, UK). Protein bands were quantified by densitometry using a GS-710 Densitometer (Bio-Rad), normalized to time-matched control levels, and expressed as fold change.

Statistical analysis. All data are presented as mean \pm SD. Statistical analyses were performed with paired $t$ tests for comparisons of in vivo bilirubin production measurements, and the Mann-Whitney non-parametric rank test or unpaired $t$ test for all other measurements as appropriate. Differences were deemed statistically significant when $p<0.05$.

\section{RESULTS}

Bilirubin production. Mean $\pm \mathrm{SD}$ baseline $\mathrm{VeCO}$ value for all mice $(n=68)$ was $37.5 \pm 6.3 \mu \mathrm{L} \mathrm{CO} / \mathrm{h} / \mathrm{kg} \mathrm{BW}$. After oral administration of Mps, $\mathrm{VeCO}$ was monitored at 1, 3, 6, 24, and $48 \mathrm{~h}$ (Fig. 1). In SnMP-treated mice, VeCO significantly decreased $23 \%$ within $1 \mathrm{~h}$ of administration, with maximal decreases within $3 \mathrm{~h}$, persisting beyond $48 \mathrm{~h}$ (Fig. 1A). Within $3 \mathrm{~h}$ after ZnBG administration, a significant $15 \%$ decrease was observed, returning to baseline by $48 \mathrm{~h}$ (Fig. 1B). After ZnPP administration, $\mathrm{VeCO}$ decreased $3 \mathrm{~h}$ following $\mathrm{ZnPP}$ administration and persisted for $24 \mathrm{~h}$, but was not statistically significant (Fig. 1C). No change in $\mathrm{VeCO}$ was observed in the control group during the entire $48 \mathrm{~h}$ study period as expected (Fig. 1D). 
HO activity. HO activity time course in the liver, spleen, and intestine after Mp treatment is shown in Fig. 2. For control mice, $\mathrm{HO}$ activities in the liver, spleen, and intestine were: $96.5 \pm 14.7(n=12), 574.1 \pm 170.6(n=11)$, and $61.2 \pm$ $17.1(n=10) \mathrm{pmol} \mathrm{CO} / \mathrm{h} / \mathrm{mg} \mathrm{FW}$, respectively. After SnMP treatment, liver HO activity was significantly inhibited (67\%) within $3 \mathrm{~h}$ and persisted $(55-60 \%)$ throughout the study period (Fig. 2A). Following ZnBG and ZnPP treatment, a significant $63 \%$ and $43 \%$ inhibition was found at $3 \mathrm{~h}$, respectively, with activity returning to near control levels by $48 \mathrm{~h}$. For the spleen, $\mathrm{HO}$ activity was significantly inhibited after treatment with all Mps throughout the study period (Fig. 2B), with the greatest inhibition following SnMP treatment, then with $\mathrm{ZnBG}$, and the least with ZnPP. In the intestine, maximal (63\%) inhibition by SnMP was observed at 3h, with 37\% inhibition still present at $48 \mathrm{~h}$, although the inhibition decreased progressively with time (Fig. 2C). After $\mathrm{ZnBG}$ or $\mathrm{ZnPP}$ administration, $\mathrm{HO}$ activity was significantly inhibited (35-40\%) at 3 and $24 \mathrm{~h}$, returning to control levels by $48 \mathrm{~h}$.

HO protein. HO-1 protein levels in the liver, spleen, and intestine were determined after $3,6,24$, and $48 \mathrm{~h}$ of $\mathrm{Mp}$ treatment and are shown in Fig. 3. Levels in the liver significantly increased 3.7- and 3.1-fold at 24 and 48h after SnMP administration, respectively. No significant changes in liver HO-1 protein were observed after treatment with $\mathrm{ZnBG}$ or ZnPP, although levels gradually increased with time (Fig. 3A). Spleen HO-1 protein significantly increased 2.0 -fold at $24 \mathrm{~h}$ after SnMP administration and persisted beyond $48 \mathrm{~h}$. No significant change in the spleen was observed after treatment with $\mathrm{ZnBG}$, but significant 1.2 - to 1.3 -fold increases were observed after 24 and $48 \mathrm{~h}$ of $\mathrm{ZnPP}$ treatment (Fig. 3B). No significant changes in intestinal HO-1 protein were found after treatment with any Mp (Fig. 3C).

When HO-2 protein levels in the liver, spleen, and intestine were determined after 3, 6, 24 and 48h of Mp administration, no changes were found for any tissue (data not shown). Equal loading of samples was verified by Coomassie Blue staining.

HO-1 transcription. The results of $\mathrm{Mp}$ administration on HO-1 transcription levels 0, 3, 6, 24, and 48h after treatments are displayed in Fig. 4. After SnMP administration, HO-1 transcription in the abdominal region increased by $3 \mathrm{~h}$, significantly peaked to 5.7 -fold by $24 \mathrm{~h}$, and decreased to 2.6 -fold by 48h (Fig. 4A). In ZnBG-treated mice, HO-1 transcription increased 2.0-fold after $6 \mathrm{~h}$, although not significantly, return-

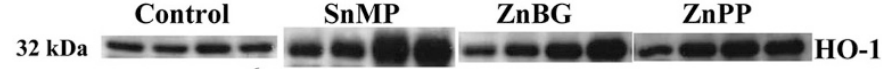

A.
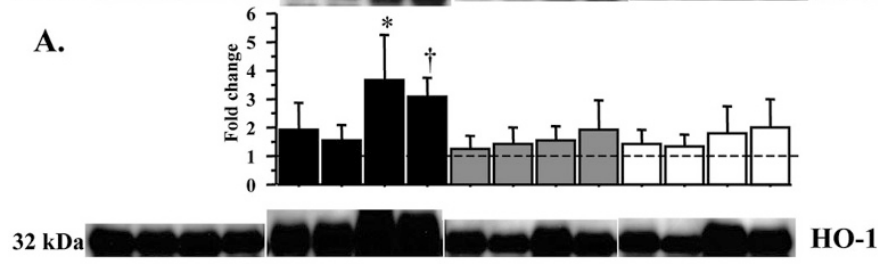

B.
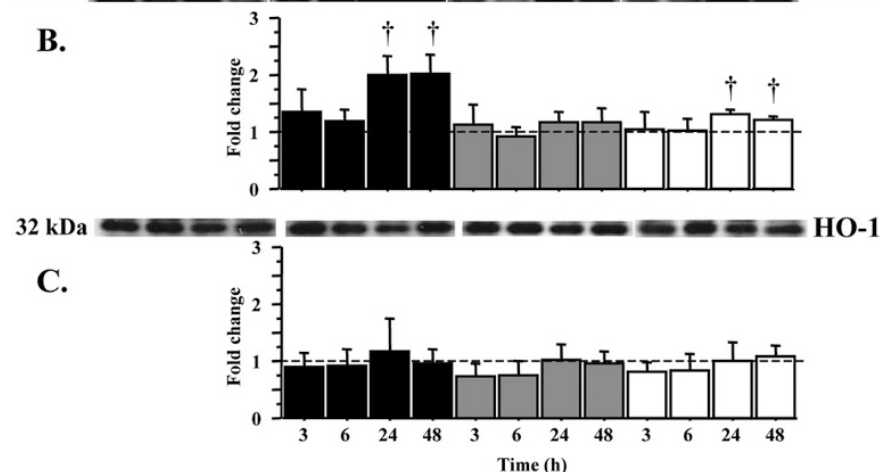

Figure 3. HO-1 protein levels after oral administration of Mps. HO-1 protein levels in the liver ( $A, n=5$ for each group and time point), spleen $(B, n=5)$, and intestine $(C, n=5)$ at $3,6,24$ and $48 \mathrm{~h}$ following oral administration of $30 \mu \mathrm{mol} / \mathrm{kg}$ BW of SnMP (black), ZnBG (gray), ZnPP (white), or vehicle (control). Values are shown as mean $\pm \mathrm{SD}$ fold increase over control levels. $\dagger p<0.01, * p<0.05$ compared with time-matched control mice.

ing to control levels by $24 \mathrm{~h}$ (Fig. 4B). In ZnPP-treated mice, no significant changes in HO-1 transcription were observed until 48h post-administration (1.7-fold) (Fig. 4C).

Correlation between in vivo BLI and native $\mathrm{HO}-1$ and luc mRNA levels. In a separate group of animals $(n=4)$, tissues were harvested after BLI to correlate $l u c$ activity with $l u c$ and HO-1 mRNA levels. Figure 5A shows representative in vivo images of the abdominal (ventral) region of control and SnMP-treated mice $24 \mathrm{~h}$ post-treatment. When fold change from control was calculated (Fig. 5B), HO-1 transcription in SnMP-treated mice increased 6.1-fold from pre-treatment levels (pre-treatment: $4.5 \times 10^{5}$ versus post $24 \mathrm{~h}: 28.4 \times 10^{5}$ photons/s, respectively) compared with controls (pretreatment: $4.6 \times 10^{5}$ versus post $24 \mathrm{~h}: 6.2 \times 10^{5}$ photons $/ \mathrm{s}$, respectively). Pre-treatment levels of both groups were similar (Fig. 5B).

Figure $5 C$ shows representative ex vivo images taken from the liver, spleen, and intestine of these mice. All SnMP-treated
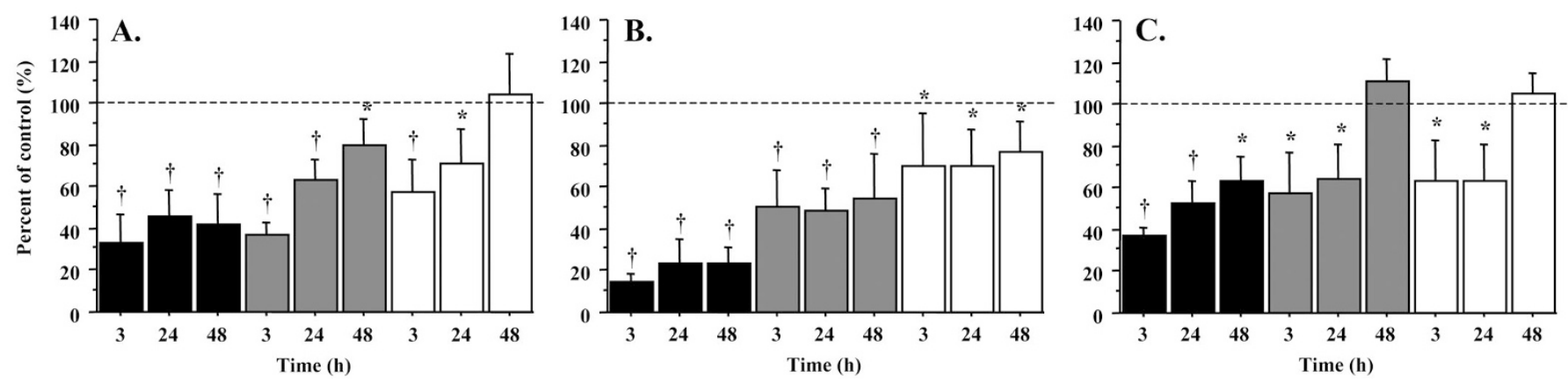

Figure 2. Mean $\pm \mathrm{SD} \% \mathrm{HO}$ activity left in the liver $(A)$, spleen $(B)$, and intestine $(C) 3,24$, and $48 \mathrm{~h}$ after oral administration of $30 \mu \mathrm{mol} / \mathrm{kg} \mathrm{BW}$ of SnMP (black), ZnBG (gray), or ZnPP (white), $n=5-7$ mice for each time point. $\dagger p<0.01,{ }^{*} p<0.05$ compared with the control levels. 

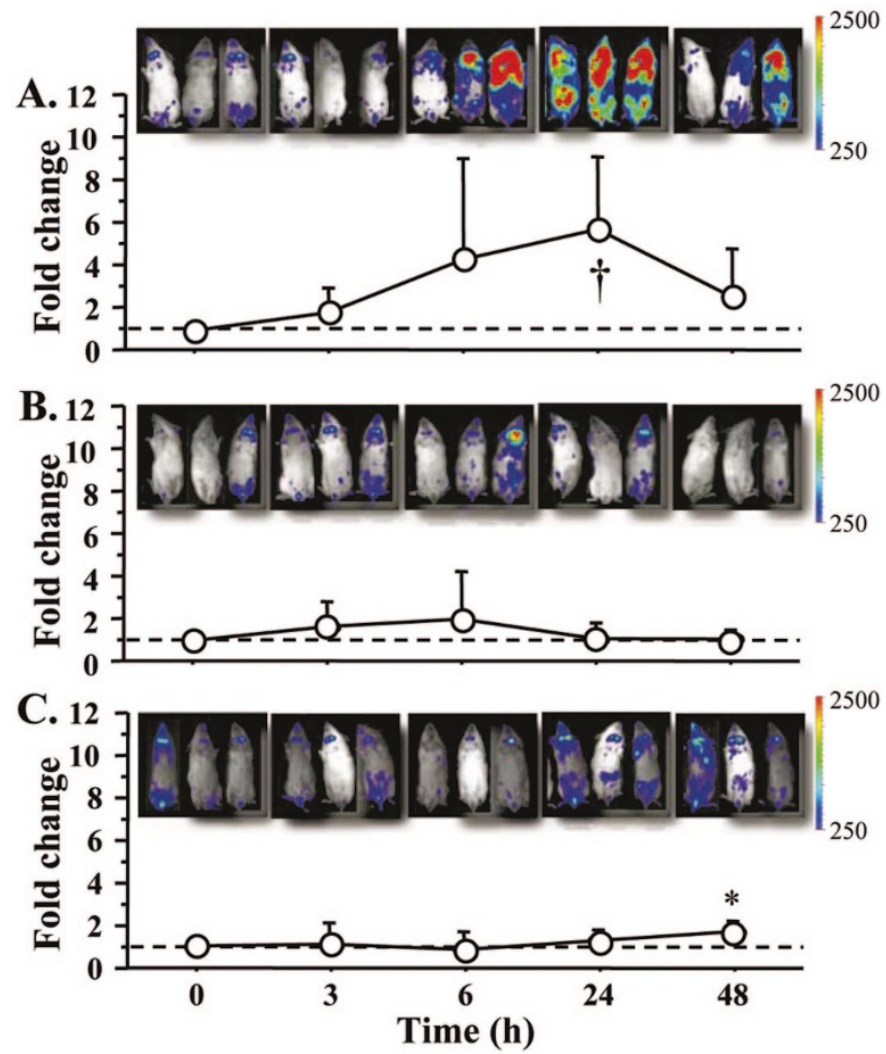

Figure 4. In vivo HO-1 transcription rates were assessed using the IVIS. Representative images from three separate studies are shown at baseline and 3, 6, 24 and 48h after treatment with Mp. All images are displayed at the same ranges (see rainbow scale) and quantitated as the total number of photons emitted from the abdominal region at each time point. Results expressed as fold change (mean $\pm \mathrm{SD}$ ) from baseline levels and then normalized to control mice (dotted line) after treatment with $30 \mu \mathrm{mol} / \mathrm{kg}$ BW of SnMP $(A), \mathrm{ZnBG}$ $(B)$, or $\mathrm{ZnPP}(C), n=5-10$ mice for each time point. $\dagger p<0.01, * p<0.05$ compared with controls.

tissues had higher signal intensities than that of control tissues. When RT-PCR was performed on these tissues, signal intensities correlated not only with $l u c$ mRNA, but also with native HO-1 mRNA for each tissue (Fig. 5D,E).

\section{DISCUSSION}

Some $\mathrm{Sn}$ and $\mathrm{Zn} \mathrm{Mps,} \mathrm{those} \mathrm{that} \mathrm{are} \mathrm{competitive} \mathrm{inhibitors}$ of $\mathrm{HO}$, have been proposed as potential drugs for the treatment of severe neonatal hyperbilirubinemia. Early clinical studies performed on human newborns with hemolytic jaundice, such as Rhisoimmunization or ABO incompatibility, glucose-6phosphate dehydrogenase deficiency, or breastfeeding jaundice showed that the intramuscular (IM) administration of $6-\mu$ moles of $\mathrm{SnMP} / \mathrm{kg} \mathrm{BW}$ is effective in preventing the development of severe hyperbilirubinemia (7-10). Oral administration of drugs is more desirable because this route is less invasive than IM and IV (intravenous) injections, and is more convenient in the outpatient setting. Previous reports have shown that some Mps, such as $\mathrm{ZnPP}$, tin protoporphyrin (SnPP), and zinc mesoporphyrin (ZnMP) are not orally absorbed by rats (25-27), while ZnBG (18) and chromium mesoporphyrin (CrMP) (28) are absorbed by neonatal rats.
A. Pre-Treatment 24h after Treatment B. 12 Pre-Treatment 24h after Treatment
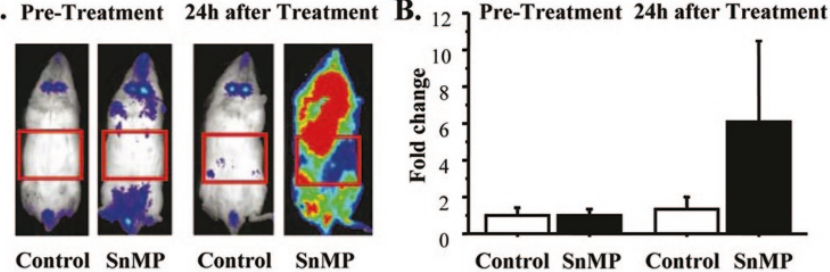

Control SnMP

Control SnMP

Control SnMP Control SnMP
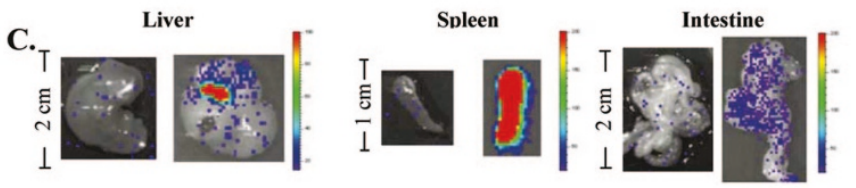

D.
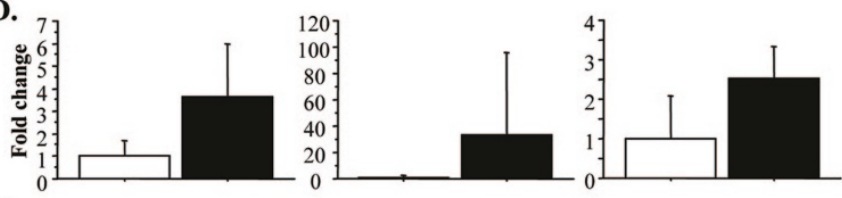

E.
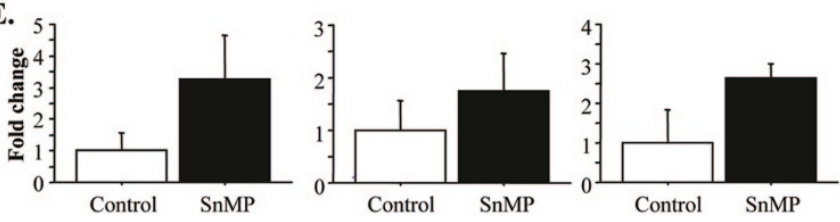

Figure 5. To show that in vivo HO-1 transcription levels as assessed by in vivo BLI is an index of transcription, $l u c$ activity and $l u c$ and HO-1 mRNA of tissues from mice treated with SnMP $(n=4)$ and vehicle (control, $n=3$ ) were correlated pre- and post $24 \mathrm{~h}$ treatment. Light emission (photons) from the abdominal region (red box) (A) was calculated as photons emitted and expressed as mean $\pm \mathrm{SD}$ fold change from baseline; $(B)$ Ex vivo images of liver, spleen, and intestine were taken using BLI $(C)$ and photon emission quantitated and compared with control levels. Total RNA from these tissues was then extracted and real-time RT-PCR was performed. Data were calculated as total number of mRNA molecules/40 ng total RNA, normalized to $\beta$-actin, and expressed as mean \pm SD fold change from control levels ( $D$ : luc mRNA, E: native HO-1 mRNA).

However, there is little information regarding the absorption and the potency of Mps in the mouse.

Because heme degradation by $\mathrm{HO}$ produces equimolar amounts of $\mathrm{CO}$ and bilirubin, measurements of $\mathrm{VeCO}$ can serve as an index of bilirubin production $(21,29,30)$. In the present study, we found that VeCO levels decreased following the oral administration of SnMP, ZnBG, or ZnPP, demonstrating that they are absorbed in the adult mouse. These observations are in contrast to findings reported in rats where $\mathrm{ZnPP}$ was not orally absorbed (27). These Mp absorption differences may be due to species differences in gastrointestinal $\mathrm{pH}$, bacterial flora, or characteristics of the intestinal epithelial cells and should be considered when human studies are initiated. The most potent inhibitor was SnMP, followed by $\mathrm{ZnBG}$, and then ZnPP. In addition, SnMP had long-lasting effects $(>48 \mathrm{~h})$, while the effects of $\mathrm{ZnBG}$ and $\mathrm{ZnPP}$ were short-acting as $\mathrm{VeCO}$ returned to baseline within $48 \mathrm{~h}$ of administration (Fig. 1). This in vivo variability in inhibitory potency and duration of action is probably due to their differential absorption, body distribution, rate of elimination from the body, and/or affinity for HO. These properties of Mps could be used to design therapeutic strategies that are targeted at selectively treating hyperbilirubinemia caused by a specific heme load. For example, infants with hemolytic disease or 
closed-space bleeding could be treated with a highly potent and long-lasting Mp (SnMP); whereas, transient severe hyperbilirubinemia (without an underlying disease) could be treated with a short-acting $\mathrm{Mp}$ ( $\mathrm{ZnBG}$ or $\mathrm{ZnPP})$.However, the oral absorption of Mps in humans has yet to be demonstrated.

Because the spleen and liver are the primary tissues where heme degradation occurs, we measured in vitro $\mathrm{HO}$ activity in these target tissues as well as in the intestine, a non-target tissue. When in vitro $\mathrm{HO}$ activity in liver, spleen, and intestine was measured following oral administration of SnMP, ZnBG, and $\mathrm{ZnPP}$, we found that $\mathrm{HO}$ activity mirrored that of $\mathrm{VeCO}$ (Fig. 2). Again, SnMP was the most potent and long-lasting. ZnBG was also potent, but displayed short-acting inhibition in the liver and intestine. $\mathrm{ZnPP}$ was the least potent and the shortest-acting.

$\mathrm{VeCO}$ and in vitro $\mathrm{HO}$ activity measurements show that $\mathrm{ZnBG}$ is orally absorbed in the mouse as in neonatal rats as described previously (18). Furthermore, ZnPP and SnMP are also orally absorbed in mice. This is in contrast to what we have previously observed where $\mathrm{ZnPP}$ was poorly absorbed in mice after direct administration into the intestinal lumen of the proximal region (unpublished observations). Therefore, our results suggest that $\mathrm{ZnPP}$ is absorbed through the duodenum and not likely absorbed in the stomach. Our data demonstrate that SnMP is a potent drug that can be used via oral administration in mice. Previous reports have shown that several drugs and toxic substances have species-specific absorption. Dreyfuss et al. (31) reported that the absorptive rates of nadolol, a $\beta$-adrenergic blocking agents, varies across species. Also, Roberts et al. (32) demonstrated differences between rats and mice in their absorption of cyclohexylamine after oral administration.

Because we have previously found that SnMP and $\mathrm{ZnPP}$ induce the expression of HO-1 in mice, and may negate its clinical utility (14), we further evaluated the effects of these Mps on HO-1 transcription. It is known that the HO-1 promoter is induced by several conditions and compounds acting on the transcriptional enhancer regions, such as heat-shock and metal responsive element sites $(29,33)$. In fact, we have found that the mechanism of HO-1 gene induction by Mps may be Mp-specific (unpublished observations). Our data demonstrate that in vivo BLI correlates with luc and native HO-1 mRNA levels for each tissue using SnMP-treated mice (Fig. 5) as an example. Therefore, BLI can be used to assess spatiotemporal changes of HO-1 gene expression in HO-1-luc reporter mice after treatment with Mps. We have also found that $\mathrm{Zn}^{2+}, \mathrm{Sn}^{4+}$, and $\mathrm{Cr}^{3+}$ ions alone did not induce HO-1 transcription and, therefore HO-1 induction by these Mps does not appear to be mediated by metal ions released from their breakdown (13). Besides, we have found no evidence that they are metabolized in vitro (34).

Recent studies by others show that the HO-1 promoter region contains a sequence that up-regulates the gene in response to heme or cobalt protoporphyrin (CoPP), but not other Mps, such as CrMP and SnPP $(33,35)$. However, we now find that $24 \mathrm{~h}$ after SnMP treatment, HO-1 transcription increased 6-fold (Figs. 4, 5B), but after $\mathrm{ZnBG}$ or $\mathrm{ZnPP}$ treatment, only small changes in $\mathrm{HO}-1$ gene expression were observed. A previous study reported that after IV administration, ZnBG did not affect HO-1 transcription, but in SnMPand ZnPP-treated mice, HO-1 transcription significantly increased 3- to 10-fold (14). The lower absorption of ZnPP after oral administration could explain the lower corresponding increase in HO-1 transcription compared with IV injections.

Our HO protein data confirm that some Mps can induce HO-1, while sparing HO-2, the constitutive isozyme (2). SnMP was found to increase HO-1 protein levels in liver and spleen $24 \mathrm{~h}$ after treatment. However, in vivo bilirubin production and $\mathrm{HO}$ activity of liver and spleen were still inhibited at this time point. Therefore, the concern that SnMP can affect HO-1 transcription may be of little importance since this effect is transient and may not offset its long-lasting inhibitory effect on $\mathrm{HO}$ activity in the liver and spleen. However, the contribution of HO-1 induction by SnMP to the overall effect needs to be investigated in a heme-loaded (increased HO substrate) model, mimicking hemolytic conditions

The doses of SnMP used in this study greatly exceed those proposed in human studies (7-10). Further work will be needed to determine the effects of the drug at clinicallyrelevant doses. The systemic effects of oral Sn and ZnMps also need to be studied in neonatal animals

In conclusion, this report provides evidence that SnMP, $\mathrm{ZnBG}$, and $\mathrm{ZnPP}$ are orally absorbed at different rates in adult mice and differentially affect bilirubin production and $\mathrm{HO}$ expression and activity in a tissue- and time-dependent manner. It also shows that, even at the high doses used, the attenuating effect of these Mps on bilirubin production is modest, with SnMP showing the largest effect. These observations could be helpful in designing therapeutic strategies using Mps in the treatment of pathologic neonatal jaundice.

Acknowledgments. The authors thank Dr. Hui Zhao and Flora Kalish for their help with RT-PCR.

\section{REFERENCES}

1. Tenhunen R, Marver HS, Schmid R 1968 The enzymatic conversion of heme to bilirubin by microsomal heme oxygenase. Proc Natl Acad Sci U S A 61:748-755

2. Maines MD 1997 The heme oxygenase system: a regulator of second messenger gases. Annu Rev Pharmacol Toxicol 37:517-554

3. Drummond GS, Galbraith RA, Sardana MK, Kappas A 1987 Reduction of the C2 and C4 vinyl groups of Sn-protoporphyrin to form Sn-mesoporphyrin markedly enhances the ability of the metalloporphyrin to inhibit in vivo heme catabolism. Arch Biochem Biophys 255:64-74

4. Vreman HJ, Lee OK, Stevenson DK 1991 In vitro and in vivo characteristics of a heme oxygenase inhibitor: ZnBG. Am J Med Sci 302:335-341

5. Rodgers PA, Seidman DS, Wei PL, Dennery PA, Stevenson DK 1996 Duration of action and tissue distribution of zinc protoporphyrin in neonatal rats. Pediatr Res 39:1041-1049

6. Vreman HJ, Ekstrand BC, Stevenson DK 1993 Selection of metalloporphyrin heme oxygenase inhibitors based on potency and photoreactivity. Pediatr Res 33:195-200

7. Kappas A, Drummond GS, Valaes T 2001 A single dose of Sn-mesoporphyrin prevents development of severe hyperbilirubinemia in glucose-6-phosphate dehydrogenase-deficient newborns. Pediatrics 108:25-30

8. Martinez JC, Garcia HO, Otheguy LE, Drummond GS, Kappas A 1999 Control of severe hyperbilirubinemia in full-term newborns with the inhibitor of bilirubin production Sn-mesoporphyrin. Pediatrics 103:1-5

9. Reddy P, Najundaswamy S, Mehta R, Petrova A, Hegyi T 2003 Tin-mesoporphyrin in the treatment of severe hyperbilirubinemia in a very-low-birth-weight infant. J Perinatol 23:507-508

10. Valaes T, Petmezaki S, Henschke C, Drummond GS, Kappas A 1994 Control of jaundice in preterm newborns by an inhibitor of bilirubin production: studies with tin-mesoporphyrin. Pediatrics 93:1-11

11. Appleton SD, Chretien ML, McLaughlin BE, Vreman HJ, Stevenson DK, Brien JF, Nakatsu K, Maurice DH, Marks GS 1999 Selective inhibition of heme oxygenase, 
without inhibition of nitric oxide synthase or soluble guanylyl cyclase, by metalloporphyrins at low concentrations. Drug Metab Dispos 27:1214-1219

12. Vreman HJ, Wong RJ, Sanesi CA, Dennery PA, Stevenson DK 1998 Simultaneous production of carbon monoxide and thiobarbituric acid reactive substances in rat tissue preparations by an iron-ascorbate system. Can J Physiol Pharmacol 76:10571065

13. Hajdena-Dawson M, Zhang W, Contag PR, Wong RJ, Vreman HJ, Stevenson DK, Contag CH 2003 Effects of metalloporphyrins on heme oxygenase-1 transcription: correlative cell culture assays guide in vivo imaging. Mol Imaging 2:138-149

14. Zhang W, Contag PR, Hardy J, Zhao H, Vreman HJ, Hajdena-Dawson M, Wong RJ, Stevenson DK, Contag CH 2002 Selection of potential therapeutics based on in vivo spatiotemporal transcription patterns of heme oxygenase-1. J Mol Med 80:655-664

15. Hintz SR, Vreman HJ, Stevenson DK 1990 Mortality of metalloporphyrin-treated neonatal rats after light exposure. Dev Pharmacol Ther 14:187-192

16. Keino H, Nagae H, Mimura S, Watanabe K, Kashiwamata S 1990 Dangerous effects of tin-protoporphyrin plus photoirradiation on neonatal rats. Eur J Pediatr 149:278279

17. Vreman HJ, Wong RJ, Stevenson DK 2001 Alternative metalloporphyrins for the treatment of neonatal jaundice. J Perinatol 21:S108-S113; discussion S125-S127.

18. Vallier HA, Rodgers PA, Stevenson DK 1991 Oral administration of zinc deuteroporphyrin IX 2,4 bis glycol inhibits heme oxygenase in neonatal rats. Dev Pharmacol Ther 17:220-222

19. Fernandez JM, Bilgin MD, Grossweiner LI 1997 Singlet oxygen generation by photodynamic agents. J Photochem Photobiol B Biol 37:131-140

20. Zhang W, Feng JQ, Harris SE, Contag PR, Stevenson DK, Contag CH 2001 Rapid in vivo functional analysis of transgenes in mice using whole body imaging of luciferase expression. Transgenic Res 10:423-434

21. Vreman HJ, Rodgers PA, Gale R, Stevenson DK 1989 Carbon monoxide excretion as an index of bilirubin production in rhesus monkeys. J Med Primatol 18:449-460

22. Vreman HJ, Wong RJ, Kadotani T, Stevenson DK 2005 Determination of carbon monoxide $(\mathrm{CO})$ in rodent tissue: effect of heme administration and environmental CO exposure. Anal Biochem 341:280-289

23. Vreman HJ, Stevenson DK 1988 Heme oxygenase activity as measured by carbon monoxide production. Anal Biochem 168:31-38
24. Vreman HJ, Stevenson DK 1999 Detection of heme oxygenase activity by measurement of CO. In: Reed DJ, Sassa S, Sipes S (eds) Current Protocols in Toxicology. John Wiley \& Sons, Inc., New York, pp 9.2.1-9.2.10.

25. Drummond GS, Rosenberg DW, Kappas A 1992 Intestinal heme oxygenase inhibition and increased biliary iron excretion by metalloporphyrins. Gastroenterology 102:1170-1175

26. Rosenberg DW, Drummond GS, Kappas A 1989 The in vitro and in vivo inhibition of intestinal heme oxygenase by tin-protoporphyrin. Pharmacology 39:224-229

27. Vreman HJ, Hintz SR, Kim CB, Castillo RO, Stevenson DK 1988 Effects of ora administration of tin and zinc protoporphyrin on neonatal and adult rat tissue heme oxygenase activity. J Pediatr Gastroenterol Nutr 7:902-906

28. Vallier HA, Rodgers PA, Stevenson DK 1993 Inhibition of heme oxygenase after oral vs intraperitoneal administration of chromium porphyrins. Life Sci 52:PL79PL84.

29. Stevenson DK, Vreman HJ, Wong RJ, Contag CH 2001 Carbon monoxide and bilirubin production in neonates. Semin Perinatol 25:85-93

30. Vreman HJ, Wong RJ, Stevenson DK 2000 Carbon monoxide in breath, blood, and other tissues. In: Penney DG (eds) Carbon monoxide toxicity. CRC Press, Boca Raton, pp 19-60.

31. Dreyfuss J, Shaw JM, Ross JJJr 1978 Absorption of the beta-adrenergic-blocking agent, nadolol, by mice, rats, hamsters, rabbits, dogs, monkeys, and man: an unusual species difference. Xenobiotica 8:503-508.

32. Roberts A, Renwick AG 1989 The pharmacokinetics and tissue concentrations of cyclohexylamine in rats and mice. Toxicol Appl Pharmacol 98:230-242

33. Smith A, Alam J, Escriba PV, Morgan WT 1993 Regulation of heme oxygenase and metallothionein gene expression by the heme analogs, cobalt-, and tinprotoporphyrin. J Biol Chem 268:7365-7371

34. Vreman HJ, Cipkala DA, Stevenson DK 1996 Characterization of porphyrin heme oxygenase inhibitors. Can J Physiol Pharmacol 74:278-285

35. Shan Y, Pepe J, Lambrecht RW, Bonkovsky HL 2002 Mapping of the chick heme oxygenase-1 proximal promoter for responsiveness to metalloporphyrins. Arch Biochem Biophys 399:159-166 